\title{
Environmental Changes on Freshwater Fish Communities in South America in the last five decades: A Case Study in Northeast Argentina.
}

\section{Cambios ambientales sobre las comunidades de peces dulceacuícolas en}

\author{
Sudamérica en las últimas cinco décadas: un caso de estudio en el noreste de
} Argentina.

\author{
Alejandra Volpedo ${ }^{1,2} *$ y Gustavo A. Thompson ${ }^{1}$ \\ 1- Instituto de Investigaciones en Producción Animal (INPA-UBA-CONICET) Facultad de Ciencias \\ Veterinarias, Universidad de Buenos Aires, Av. Chorroarín 280, CP1427 Buenos Aires, Argentina. \\ 2- Centro de Estudios Transdisciplinarios del Agua (CETA-UBA) Facultad de Ciencias Veterinarias, \\ Universidad de Buenos Aires, Av. Chorroarín 280, CP1427 Buenos Aires, Argentina. \\ *Corresponding author: Alejandra Volpedo: avolpedo@fvet.uba.ar
}

\begin{abstract}
Environmental changes together with other stressors, such as habitat destruction, may cause widespread extinctions, decrease in biodiversity and disrupt natural communities, resulting in novel species assemblages. South America has a large diversity of freshwater fish with complex evolutionary histories, mainly due to the presence of a wide variety of aquatic environments. Argentina has experienced an increase in rainfall in the last five decades leading to important climatic and hydrological changes. These changes caused the displacement of the isohyets towards the west. This study reports changes in the composition of freshwater fish in northeast Argentina during the last five decades, and investigated a causal relationship between the variation in fish assemblages and climate change.

The changes in the distribution and composition of fish communities between 1962 and 2010 were analyzed in 22 stations. These stations were grouped in relation to the ichthyogeographic provinces: Great Rivers province (GRp) and Pampean province (Pp). The correlation between rainfall in relation to the number of total species from each of the studied provinces showed a significant positive correlation in Pp and not correlation in GRp. The annual mean river discharge and the number of total species from each ecoregion showed a significant positive correlation in GRp, and not correlation in $\mathrm{Pp}$. The results of this study strongly suggest that the rainfall variations and river discharges observed in northeast Argentina induced changes in the composition of fish assemblages that lead to the redistribution of fish species among ichthyogeographic provinces.

Keywords: environmental changes, isohyet displacement, freshwater fish distribution, northeast Argentina, South America
\end{abstract}

\section{RESUMEN}

Los cambios ambientales junto con otros factores estresantes como la destrucción del hábitat, pueden causar extinciones generalizadas, disminución de la biodiversidad y alterar las comunidades naturales, resultando en un ensamble de especies nuevas. América del Sur tiene una gran diversidad de peces de agua dulce con historias evolutivas complejas, principalmente debido a la presencia de una gran variedad de ambientes acuáticos. Argentina ha experimentado un aumento en las precipitaciones en las últimas cinco décadas que lleva a importantes cambios climáticos e hidrológicos. Estos cambios 
provocaron el desplazamiento de las isoyetas hacia el oeste. Este estudio informa de cambios en la composición de peces de agua dulce en el noreste de Argentina durante las últimas cinco décadas e investigado una relación causal entre cambio climático y la variación en los ensambles de peces. Se analizaron los cambios en la distribución y composición de las comunidades de peces entre 1962 y 2010 en 22 estaciones de muestreo. Estas estaciones fueron agrupadas en relación con las provincias de ictiogeográficas: Provincia de grandes ríos (GRp) y pampeana (Pp). La correlación entre la precipitación en relación con el número total de especies de cada una de las provincias estudiadas mostraron una correlación significativa positiva en la Pp y no correlación en la GRp. La descarga anual promedio del río y el número total de especies de cada ecorregión mostró una correlación positiva significativa en GRp y no correlacionó en Pp. Los resultados de este estudio sugieren fuertemente que las variaciones de precipitación y las descargas de los río presentes en el Noreste Argentina inducirían los cambios en la composición de los ensambles de peces que llevan a la redistribución de especies de peces entre las provincias de ictiogeográficas.

Palabras Clave: cambios ambientales, desplazamiento de isoyetas, distribución de peces dulceacuícolas, noroeste de Argentina, Sudamérica.

\section{INTRODUCTION}

Environmental changes coupled with habitat destruction, among other stressors, may lead to widespread extinctions, loss of biodiversity and the disruption of natural communities, which would result in novel species assemblages (Root et al. 2003; Thomas et al. 2004; Parmesan 2006; Williams et al. 2007). In particular, endemic species face a higher extinction risk because of their vulnerability to habitat fragmentation and narrow range of environmental tolerance (Malcolm et al. 2006; Preston et al. 2008).

Changes in fish communities and trophic chains may be reflected in changes in species distribution, in the structure and dynamics of populations, and in the ecosystem (Thomas et al. 2004; Poulard \& Blanchard 2005). Response to environmental changes is species-specific. Some species unable to adapt to changing environments may become extinct, while others with a broader range of environmental tolerance due to plasticity of physiological responses may extend their geographical distribution (Parmesan 2006; Skelly et al. 2007; Shaefer et al. 2008). Among vertebrates, freshwater fish are sensitive to habitat changes and their response varies depending on the intensity and duration of the disturbance. This characteristic makes them useful for monitoring the ecological integrity and changes in the functioning of aquatic ecosystems (Adams \& Greeley 2000). South America exhibits a large variety of freshwater fish species with complex evolutionary histories (phylogenies), mainly due to the wide diversity of aquatic environments in terms of, for example, habitat dynamics and size (Malabarba et al. 1998).

Over the last five decades, environmental changes have been documented in South America, including Argentina, (Gómez et al. 2004; Gómez \& Menni 2005; Bates et al. 2008; Avigliano et al. 2011; Volpedo et al. 2014). Particularly for this country, hydrologic changes resulting from increases in precipitation cause displacement of the isohyets towards the west, changes in land use by agricultural intensification, and unplanned urbanization (Barros et al.2000b; Bervery et al. 2006). However, the impact of isohyets displacement on the northeast Argentina's aquatic fauna has not been analyzed. In this paper, we report the results of the analysis of changes that have taken place during the last five decades in the composition of freshwater fish communities in northeast Argentina. In addition, a potential causal relationship between the obtained data and climatic change is suggested.

\section{MATERIAL AND METHODS}

The changes in the distribution and composition of fish communities between 1962 and 2010 were analyzed in 22 stations (Fig. 1). These stations were grouped in two groups in relation to the ichthyogeographic provinces proposed by López et al. (2008): Great Rivers province (GRp) (stations: 1 to 17) and Pampean province (Pp) (stations: 18 to 22). Fish diversity of each station was analyzed. Published information, including Ringuelet 1962; Ringuelet et al.1967; Bonetto et al. 1978; Arratia et al. 1983; Menni et al. 1992; Menni et al. 1996; López et al. 2002; López \& Miquelarena 2005; 
Monasterio de Gonzo 2003; López et al. 2003; Menni 2004; Menni et al. 2005; Liotta 2006, 2014 as well as our own data, was utilized for this analysis. The selected stations included individual streams, small water courses, lentic environments, and rivers (Fig. 1).

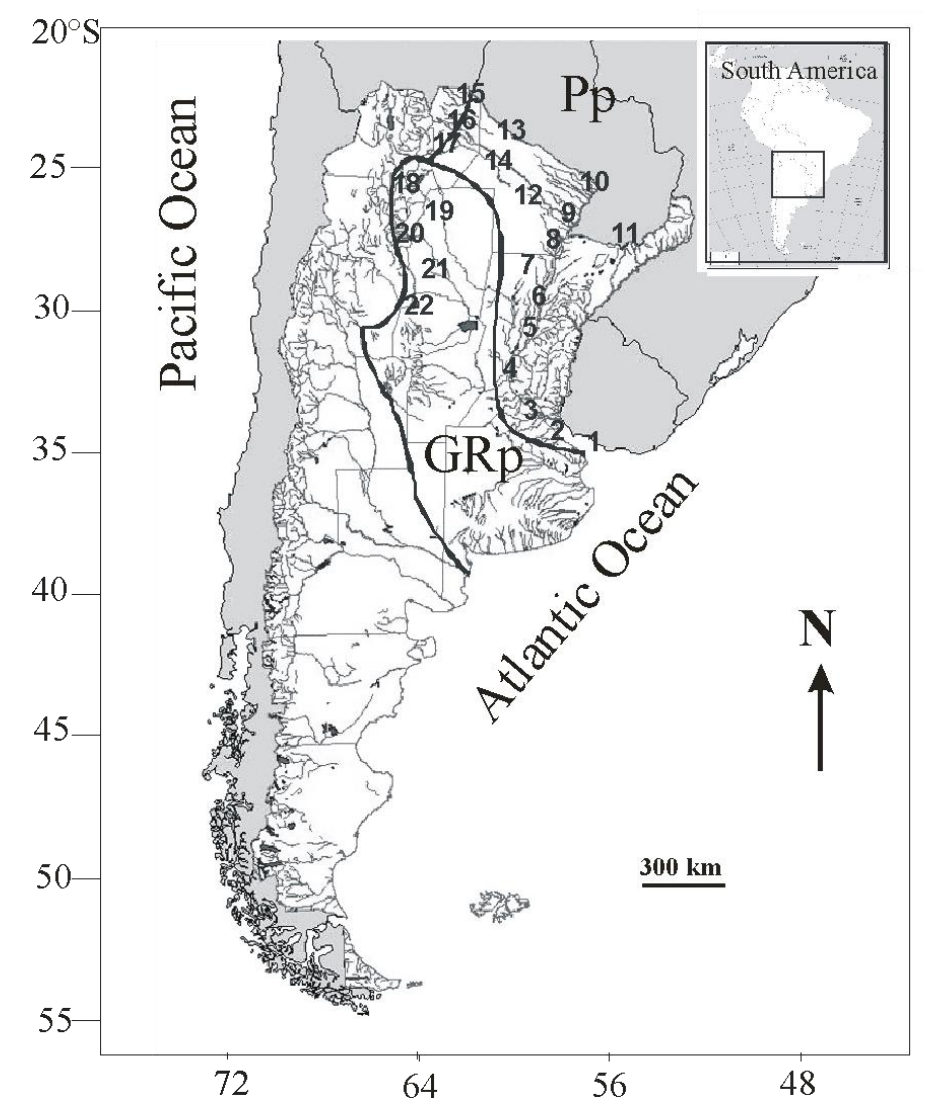

Fig. 1 Ichthyogeographic provinces studied of Argentina and sampling sites. GRp: Great Rivers province, $\mathrm{Pp}$ : Pampean province. La Plata River and its tributaries (1), Paraná River delta (2), Middle and Lower Paraná River (3,4), Middle Paraná River (5, 6, 7), Paraná- Bermejo Confluence (8), Lower Paraguay River $(9,10)$, Upper Paraná River (11), Formosa swamp zone (12), Pilcomayo River (13, 15), Bermejo River (14, 16, 17), Juramento River (18, 19), Salí-Dulce River (20, 21, 22).

The presence or absence of species was investigated, which resulted in an absence/presence binary matrix. A binary matrix built with species restricted to each one of the ichthyogeographical provinces, and species shared by both provinces was elaborated for each decade. Taxa reported as introduced and/or lying on the border area between provinces were not included in the analysis to avoid overestimating the number of species.

Monthly total rainfall data and mean river discharge data from hydrometeorological stations localized in the studied areas were analyzed for the period 1962-2010. The meteorological data was provided by the National Weather Center (meteorological stations: Tartagal Aero: $22^{\circ} 39^{\prime} \mathrm{S}, 63^{\circ} 50^{\prime} \mathrm{W}$; Las Lomitas: $24^{\circ} 42^{\prime} 26^{\prime}$ 'S, $60^{\circ} 35^{\prime} 40^{\prime}$ 'W; La Plata: $34^{\circ} 58^{\prime} \mathrm{S}, 57^{\circ} 54^{\prime} \mathrm{W}$; Tucuman Aero: $26^{\circ} 51^{\prime} \mathrm{S}, 65^{\circ} 10^{\prime} \mathrm{W}$; Faimalla Inta: $27^{\circ} 03^{\prime} \mathrm{S}, 6^{\circ} 25^{\prime} \mathrm{W}$; and Ceres Aero: $\left.29^{\circ} 53^{\prime} \mathrm{S}, 61^{\circ} 60^{\prime} \mathrm{W}\right)$.

The mean river discharge date was provided by the Secretary of Water Resources (hydrometeorological stations: Balapuca: 22 $31^{\prime} \mathrm{S}, 64^{\circ} 26^{\prime} \mathrm{W}$; La Paz: $22^{\circ} 22^{\prime} \mathrm{S}, 62^{\circ} 32^{\prime} 21^{\prime \prime} \mathrm{W}$; El

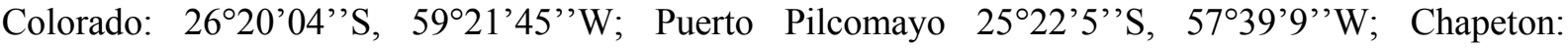

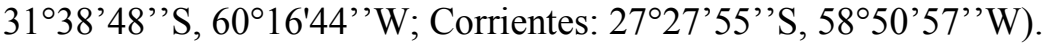

The Spearman rank correlation coefficient was used to assess the correlation between the environmental variables (precipitations and mean river discharge) and species number in the different decades studied (Zar 1999). The Jaccard's Similarity Index was used to analyze similarities in species composition between the two ichthyogeographical provinces for each decade; it was calculated with 
the formula $\left[\mathrm{C} /\left(\mathrm{N}_{1}+\mathrm{N}_{2}-\mathrm{C}\right)\right]$, where $\mathrm{C}$ is the number of species shared by both regions, and $\mathrm{N}_{1}$ and $\mathrm{N}_{2}$ are the number of species in each of the two regions (Magurran 1988). The Jaccard index ranges from 0 (no species shared) to 1 (all species shared). The Spearman correlation was applied between the values of the Jaccard index and the different decades studied (Zar 1999).

\section{Study area}

Great Rivers ichthyogeographic province (GRp): the GRp includes the area drained by the lower third of the course of Pilcomayo River, the lower course of Paraguay River and the entire Bermejo River basin. In addition, it includes the area of sloughs and marshes in Chaco, Formosa and Santa Fe provinces, the Riachuelo basin and Iberá system in Corrientes province, the Corrientes river basin, the area of sub-meridional lowlands and the alluvial plains of Middle and Lower Paraná River, the Paraná Delta and the La Plata River up to its limit with the marine front (López et al. 2002). This area covers approximately $375700 \mathrm{~km}^{2}$ and includes diverse wetlands, which are comprised of rivers, creeks and slow-draining water bodies that form marshes and sloughs. Wetlands cover extended areas and posses high hydrological complexity. The precipitations, the mean discharge and regional floods, arising mainly in the Paraná and Paraguay systems but also in Bermejo and Pilcomayo rivers, also contribute their waters to these lentic water bodies. Mean discharge of Bermejo River, Pilcomayo River, Paraguay River and Parná River have increased in recent decades (Fig. 2). These increases were first detected in the 70's, apparently related to a higher intensity of ENSO (Barros et al. 2000a,b).

Pampean ichthyogeographic province $(\mathrm{Pp})$ : this area includes a section of Juramento, SalíDulce, San Francisco course, Tercero, Cuarto, and Carcarañá Rivers. The Pp covers approximately $417200 \mathrm{~km}^{2}$ (López et al. 2002) includes wetlands and posses a great hydrological complexity. In this region, rainfall has notably increased and caused a 100-150 km westward displacement of the $800 \mathrm{~mm}$ isohyets (Figs. 3 and 4). The shift in isohyets has led to changes in land use including an expansion of the agricultural areas and a reduction of the area for livestock production (Barros et al. 2000a,b, 2006; Baldi et al. 2006; Baldi and Paruelo 2008).

\section{RESULTS}

Temporal variability and distribution patterns of freshwater fish in northeast Argentina The number of fish species in the studied ichthyogeographic provinces has been increasing in the last five decades (Table 1). In the case of the GRp the new reported species have their type localities in Brazil and Paraguay. In Argentina, the first reports occurred in the upper, middle, and lower Paraná River (Liotta 2006). A similar situation is found in the Pp during the 1970s. However, during the 1980s in in the Pp began to appear species recorded in La Plara Basin (La Plata River, the lower Paraná River, and in the Paraná Delta).

The amount of rainfall and the number of total species from each ecoregion showed a significant positive correlation in $\mathrm{Pp}(\mathrm{r}=0.98, P<0.001)$, and not correlation in GRp $(\mathrm{P}>0.05)$.

The annual mean river discharge and the number of total species from each ecoregion showed a significant positive correlation in GRp $(\mathrm{r}=0.85, P<0.05)$, and not correlation in $\mathrm{Pp}(\mathrm{P}>0.05)$.

The GRp showed a higher fish diversity (Table 1), possibly due to a larger number of wetlands, a higher diversity of soil types, and milder climate conditions (abundant rainfall and narrow thermal amplitude) (López et al. 2002). Rainfall in GRp and Pp increased in the last decades (Figs. 3 and 4). In some cases, the increase in rainfall is reflected in an increased flow of water bodies. The mean river discharge increased in the GRp and Pp (Fig. 2a-f). 


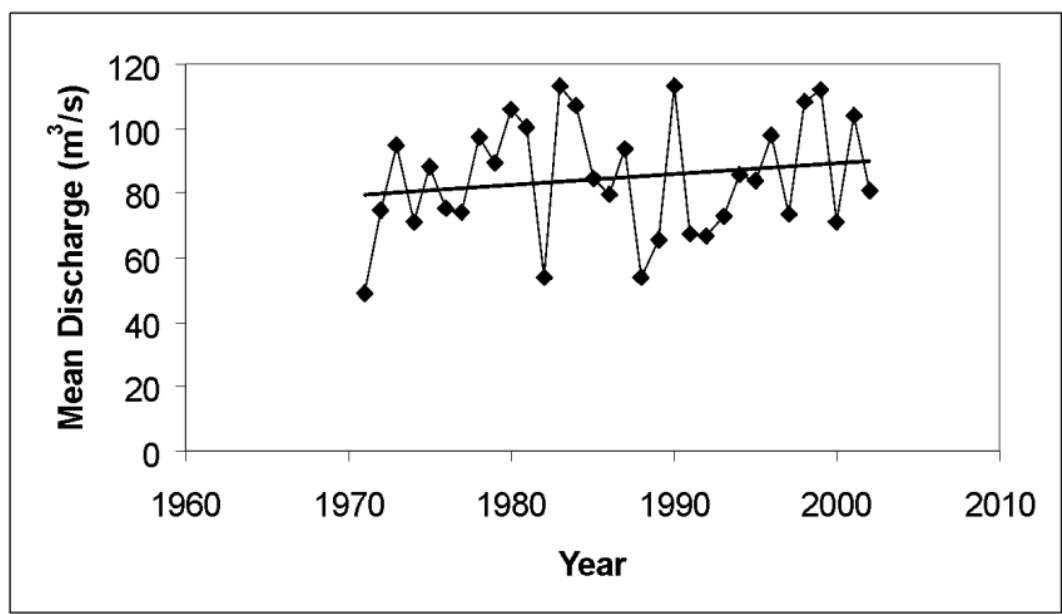

Fig. 2 a: Bermejo River, Balapuca hydrometeorological Station

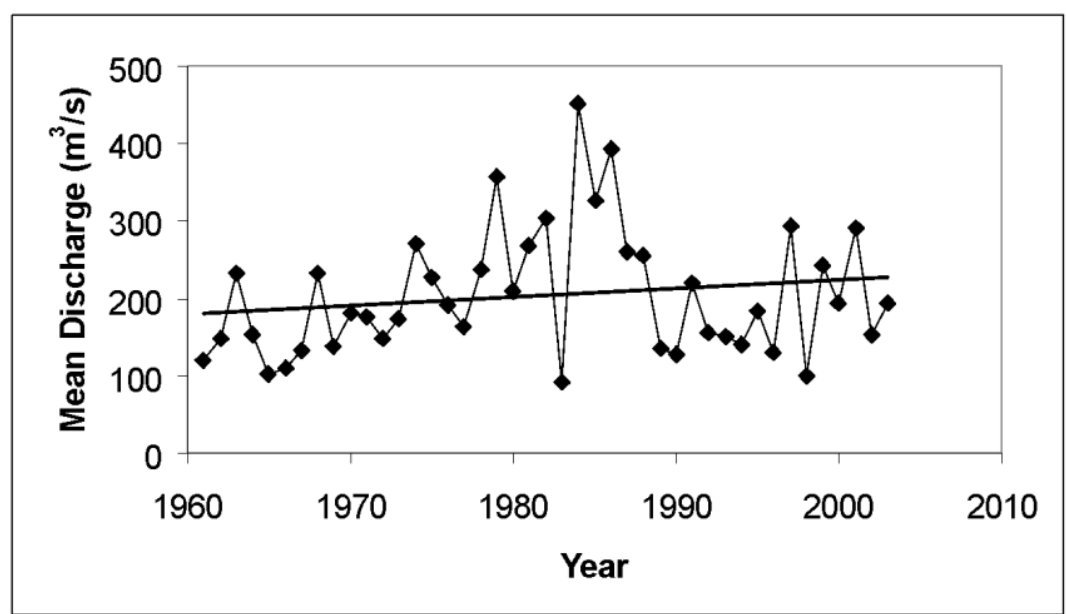

Fig. 2 b: Pilcomayo River, La Paz hydrometeorological Station

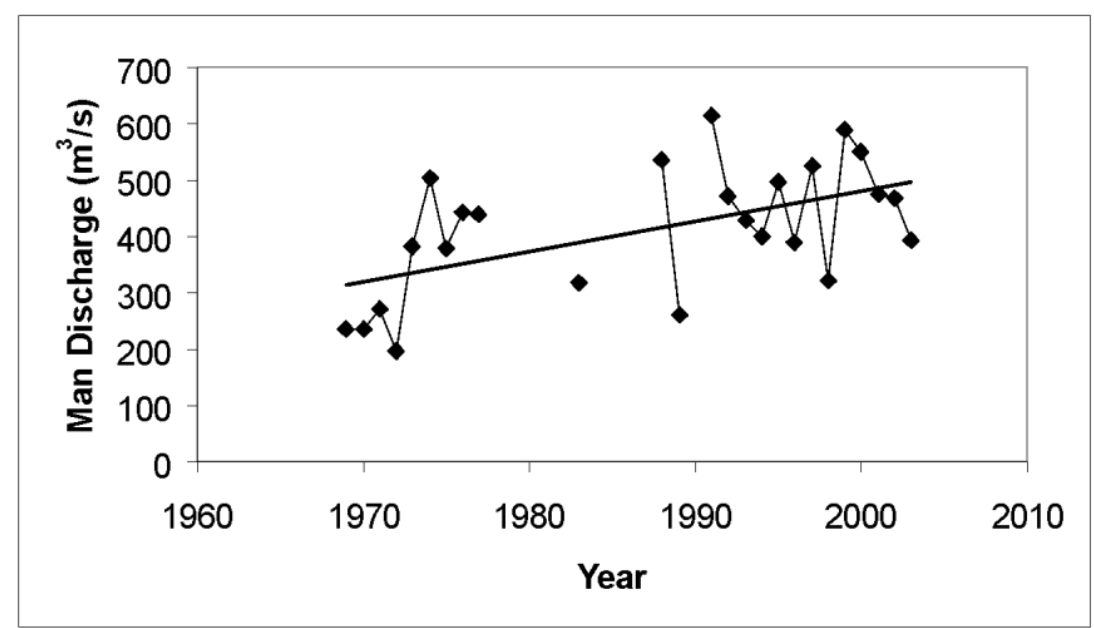

Fig. 2 c: Bermejo River, El Colorado hydrometeorological Station 


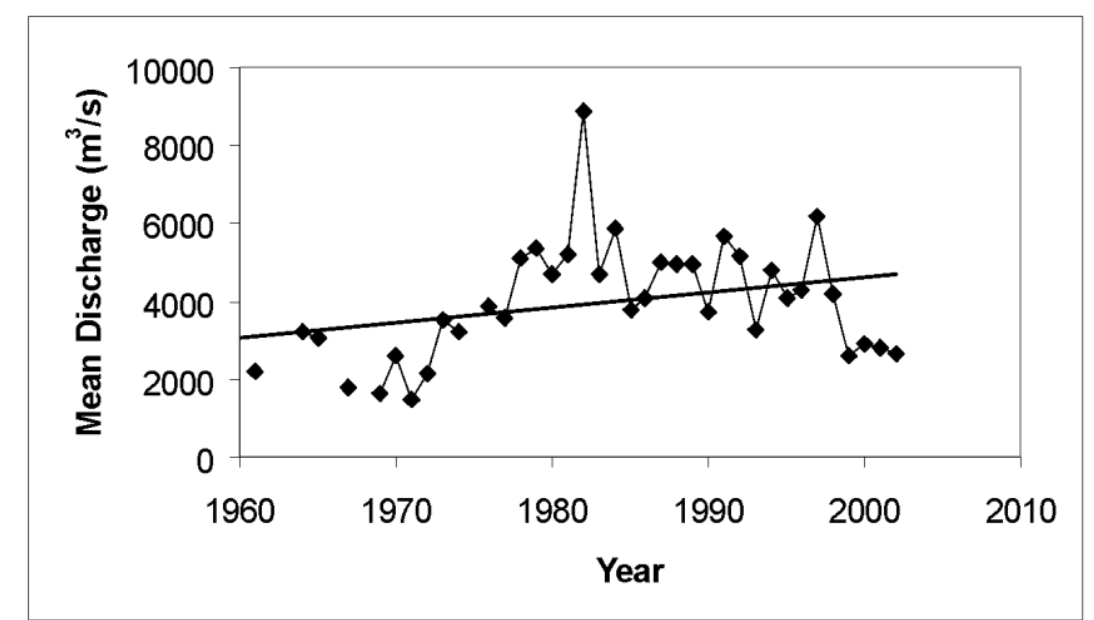

Fig. 2 d: Paraguay River, Puerto Pilcomayo hydrometeorological Station

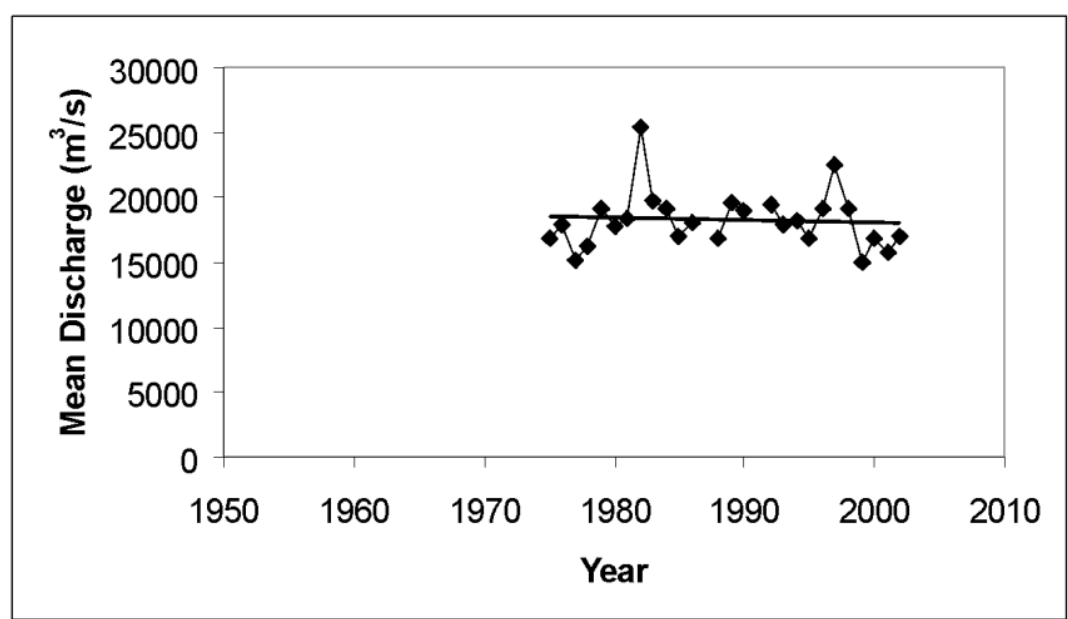

Fig. 2 e: Paraná River, Chapetón hydrometeorological Station

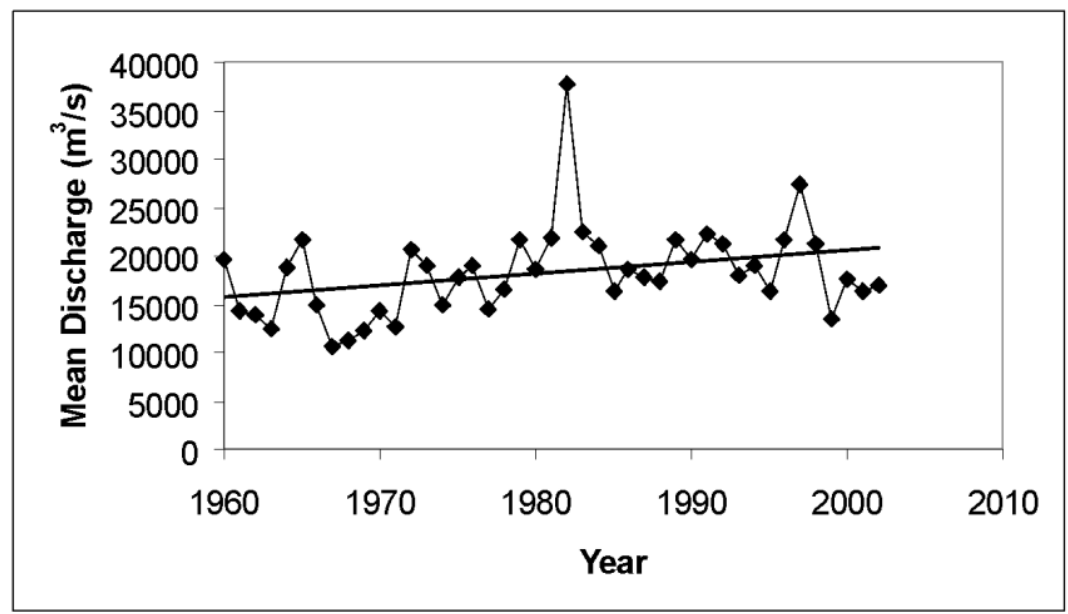

Fig. 2 f. Paraná River, Corrientes hydrometeorological Station

Figure 2. Tends of mean river discharge in hydrometeorological stations included in ichthyogeographic provinces studied. a: Balapuca; b: La Paz; c: El Colorado; d: Puerto Pilcomayo; e: Chapeton; f: Corrientes. 


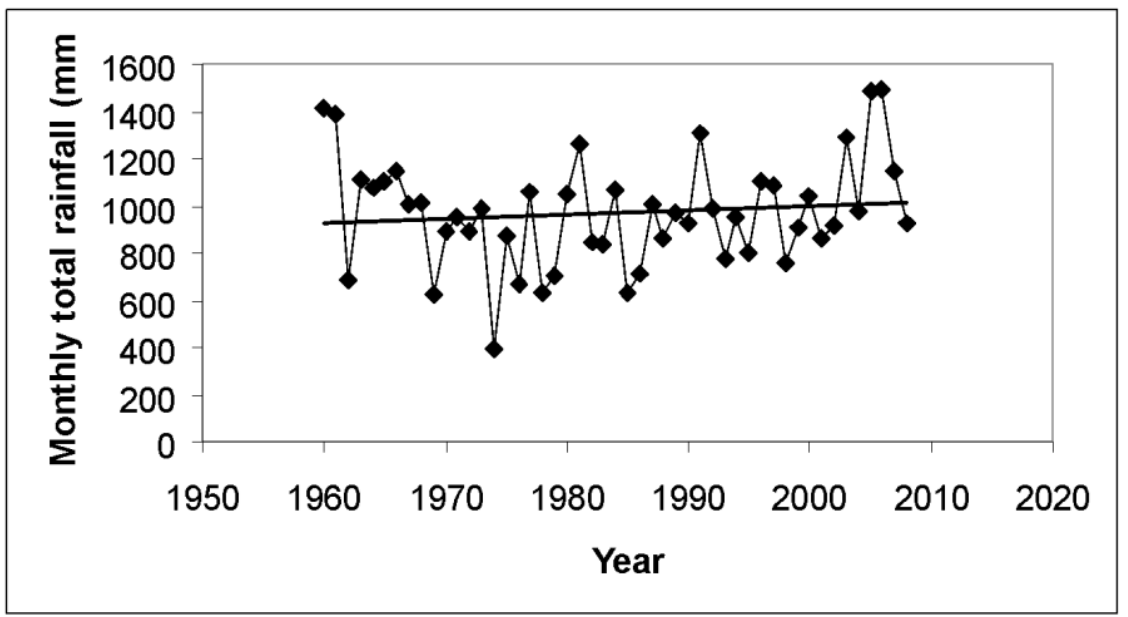

Fig. 3a. Tartagal Aero meteorological station.

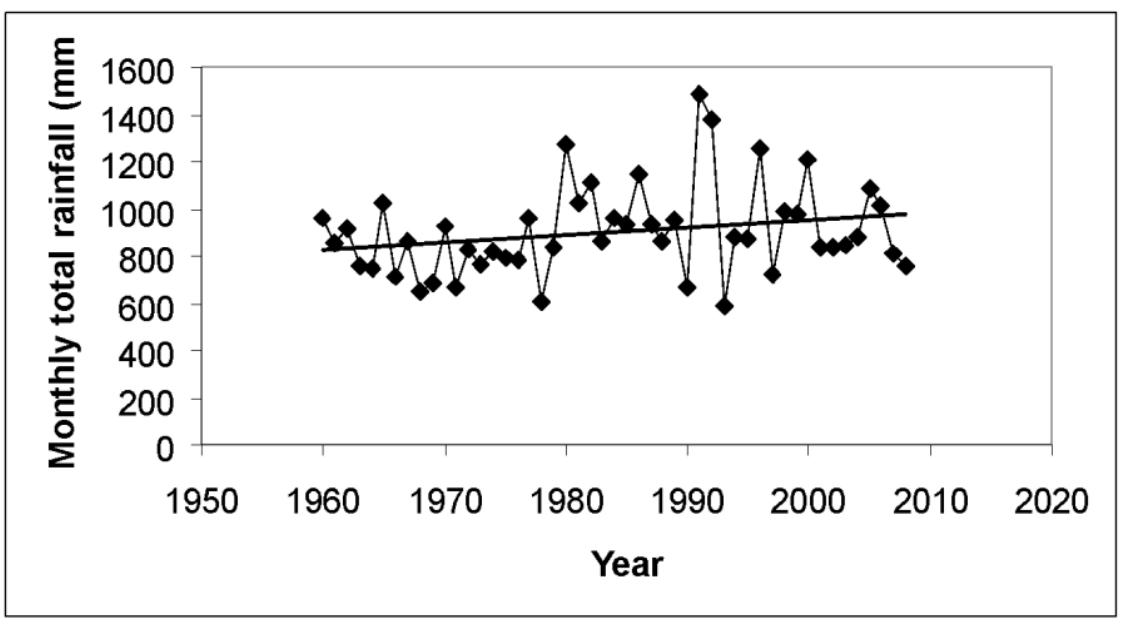

Fig. 3b. Las Lomitas meteorological station

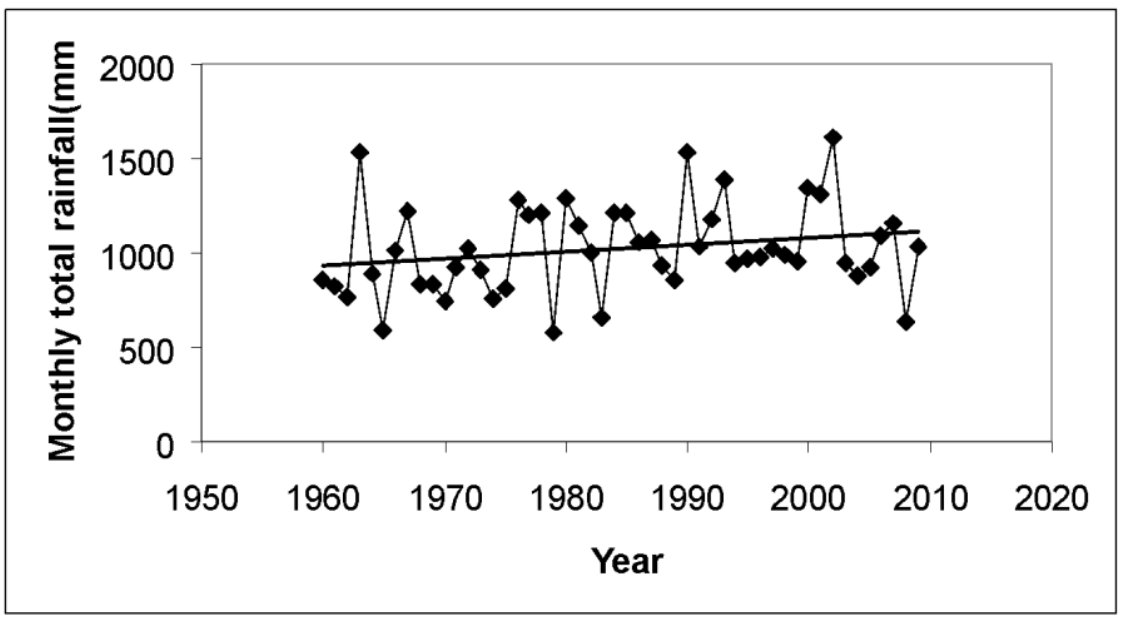

Fig. 3c. La Plata Aero meteorological station 


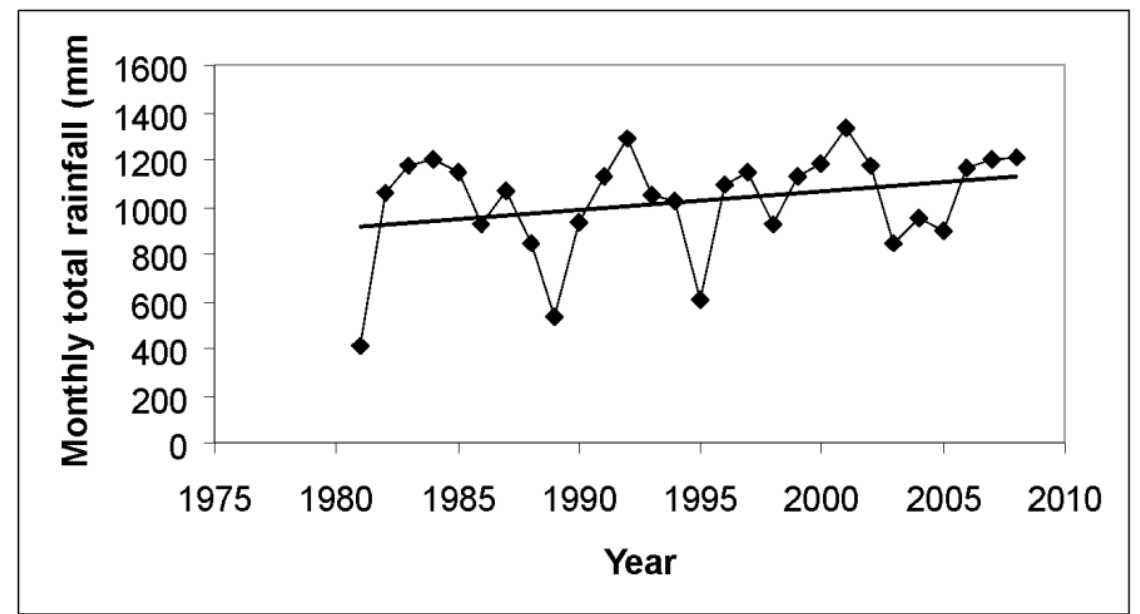

Fig. 3d. Tucuman Aero meteorological station.

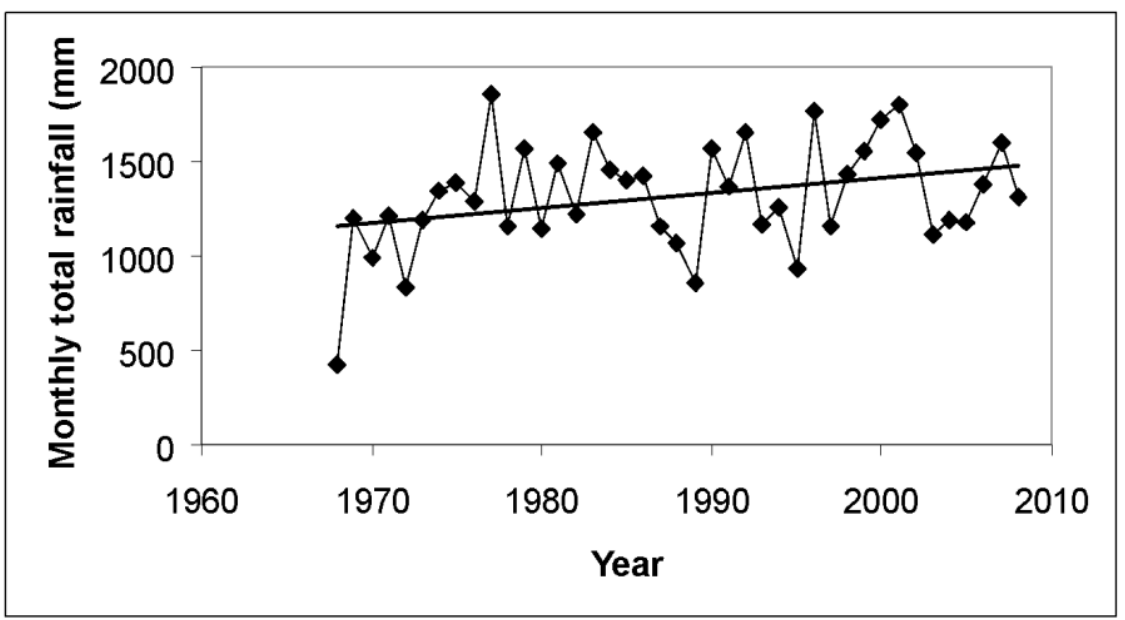

Fig. 3e. Faimalla Inta meteorological station.

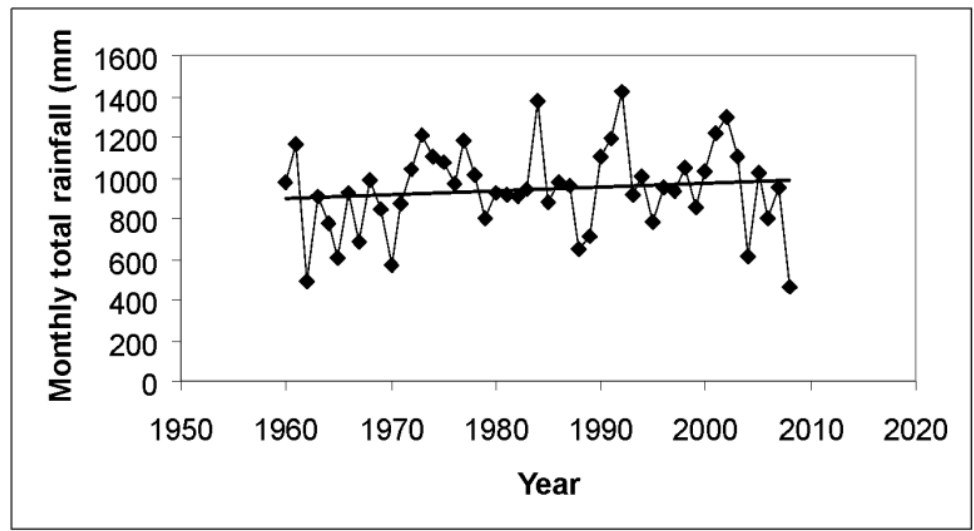

Fig. 3f. Ceres meteorological station.

Fig. 3. Tends of monthly total rainfall increment of meteorological stations included in ichthyogeographic provinces studied. a: Tartagal Aero, b: Las Lomitas, c: La Plata Aero, d: Tucuman Aero, e: Faimalla Inta, f: Ceres Aero. 
Table 1. Fish composition of icthyogeographic province studied: Great Rivers province (GRp) and Pampean province (Pp) of the last five decades. Totals correspond to the number of species identified for the first time in each decade.

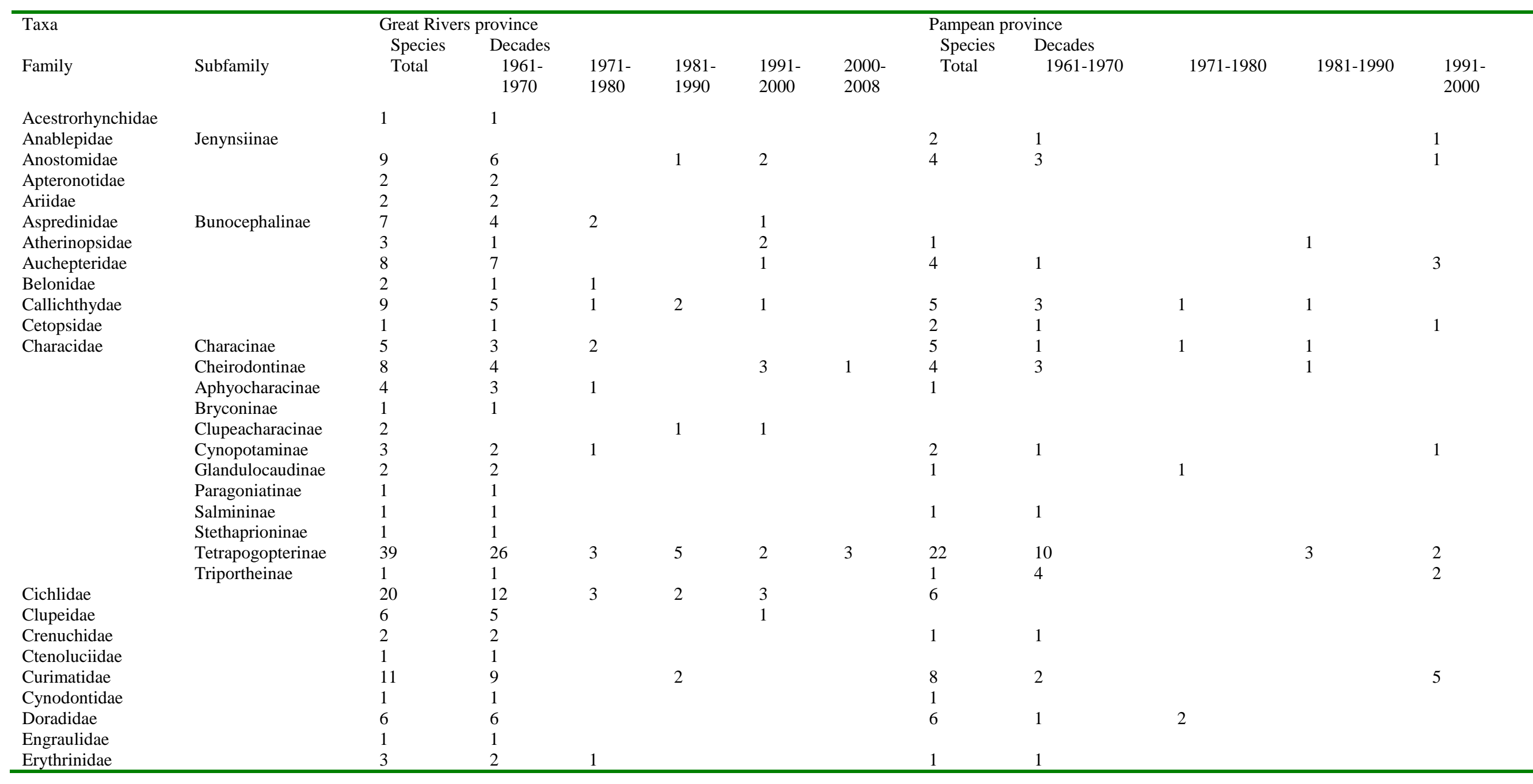


Sustainability, Agri, Food and Environmental Research 4(3), 2016: 47-61 ISSN: 0719-3726

\begin{tabular}{|c|c|c|c|c|c|c|c|c|c|c|c|c|}
\hline Gymnotidae & & 1 & 1 & & & & & 1 & & & & \\
\hline Hemiodintidae & & 1 & 1 & & & & & 1 & & & & \\
\hline Hypopomidae & & 1 & 1 & & & & & 1 & 1 & & & \\
\hline Lebiasinidae & Pyrrhulininae & 2 & 2 & & & & & & & & & \\
\hline Lepidosirenidae & & 1 & 1 & & & & & 1 & 1 & & & \\
\hline \multirow[t]{5}{*}{ Loricariidae } & Hypoptopomatinae & 5 & 4 & & & 1 & & 1 & & & & \\
\hline & Acistrinae & 2 & 2 & & & & & & & & & \\
\hline & Hypostominae & 11 & 5 & 1 & & 4 & 1 & 5 & 2 & 2 & 1 & \\
\hline & Loricariinae & 15 & 7 & 5 & 1 & 1 & 1 & 10 & 3 & & 1 & 1 \\
\hline & Neoplecostomatidae & 1 & 1 & & & & & & & & & \\
\hline Mugilidae & & 2 & 2 & & & & & & & & & \\
\hline Parondotidae & & 2 & 1 & 1 & & & & 3 & 2 & & 1 & \\
\hline \multirow[t]{3}{*}{ Pimelodidae } & Heptapterinae & 6 & 6 & & & & & 7 & 3 & 2 & & 1 \\
\hline & Pimelodinae & 20 & 18 & & & 2 & & 11 & 2 & 3 & & \\
\hline & Pseudopimelodinae & 1 & & 1 & & & & 2 & & & & \\
\hline Poeciliidae & Poeciliinae & 6 & 4 & & 1 & & 1 & 1 & & & & 1 \\
\hline Potamotrygonidae & & 6 & 5 & & & & 1 & 3 & & & & \\
\hline Prochilodonidae & & 1 & 1 & & & & & 1 & 1 & & & \\
\hline Rhamphichthyidae & & 1 & 1 & & & & & & & & & \\
\hline Rivulidae & & 7 & 5 & & & 2 & & 8 & 2 & & & 4 \\
\hline Sciaenidae & & 3 & 2 & & & & 1 & 1 & & & & \\
\hline Serrasalmidae & & 7 & 5 & & 1 & 1 & & 5 & 2 & & & \\
\hline Sternopygidae & & 3 & 3 & & & & & & & & & \\
\hline Symbranchidae & & 2 & 2 & & & & & 2 & 1 & & & \\
\hline Tricomycteridae & & 11 & 3 & 1 & 1 & 3 & 3 & 9 & 4 & & 1 & 1 \\
\hline Totals & & 281 & 197 & 24 & 17 & 31 & 12 & 151 & 58 & 12 & 12 & 23 \\
\hline
\end{tabular}




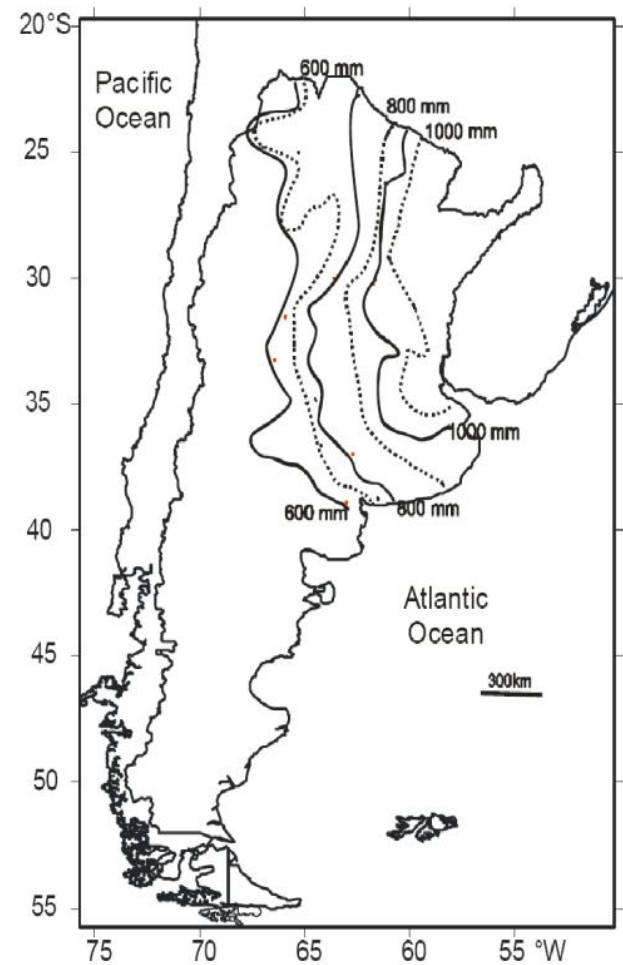

Fig. 4 Isohyets displacement in northeast Argentina (Barros et al. , 2006). Point line 1950-1969, black line 1980-1999.

The number of exclusive and shared fish species varied during the last five decades (Fig. 5). The number of exclusive fish species decreased in GRp and remained constant in Pp. However, there was a significant increase in the number of fish species shared between both ichthyogeographic provinces (Fig. 5). The number of shared species ranged between 39 and 51 from 1961 to 1979, and between 65 and 80 from 1981 and 2010. Such increase is reflected in the values of the Jaccard index, which are positively correlated with time $(r=0.96, \mathrm{P}<0.007)$ (Fig. 6).

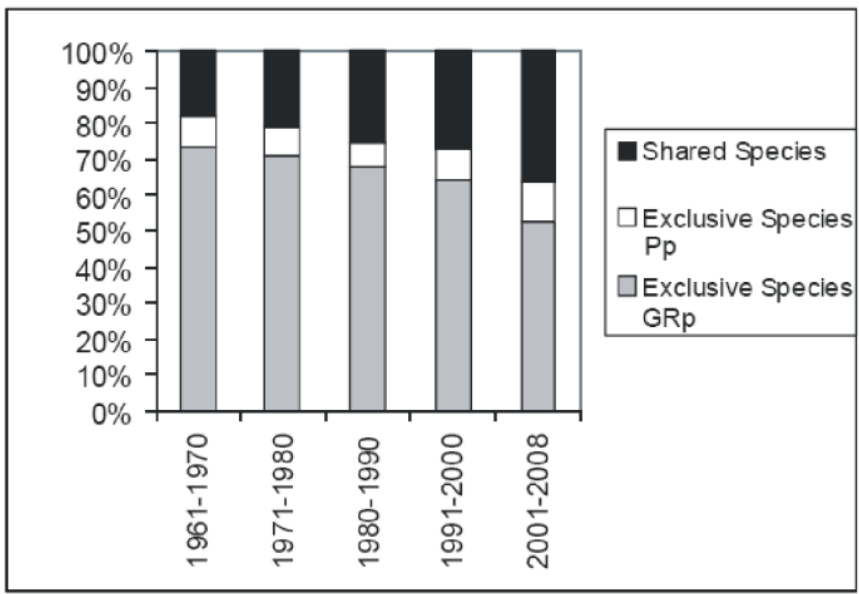

Fig. 5 Exclusive and shared species (\%) in the analyzed decades. GRp: Great Rivers province, Pp: Pampean province. 


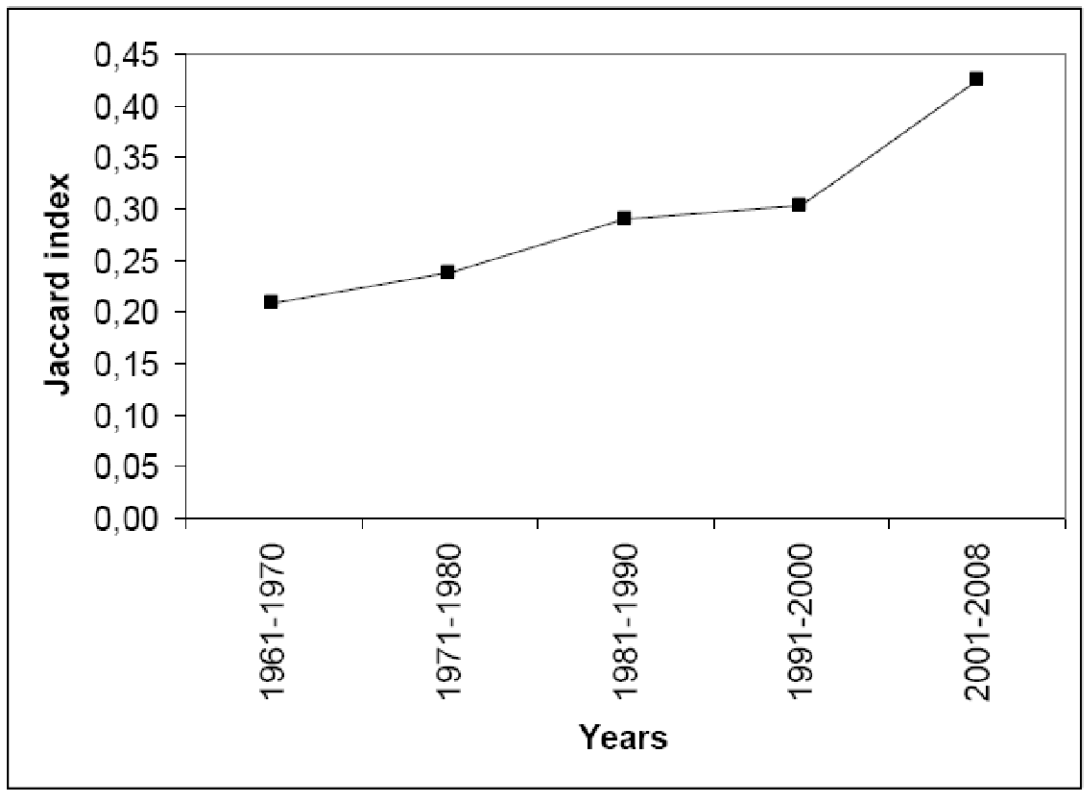

Fig.6 Variation of Jaccard index values in the last five decades.

\section{DISCUSSION}

The results of this study indicate that in northeast Argentina, as in other regions of South America, the increase in rainfalls and mean river discharge due to climate change (Barros et al. 2006, 2015; Camillioni et al. 2013) may have affected the biodiversity and distribution of freshwater fish communities over the last five decades.

The number of fish species increased in $\mathrm{Pp}$ in last decades together with the increase in rainfall. These species originally restricted to the GRp appeared in the Pp after the 80's, because the number of fish species shared between the two ichthyogeographic provinces increased in this decade. This fish displacement towards the west coincides with the increased precipitation, which was evident in the westward displacement of the $800 \mathrm{~mm}$ isohyets.

The number of fish species increased in GRp in last decades together with the increase in mean river discharge. Some of these species are native to Paraguay and Brazil which have been recorded for the first report. The increase in the flow of great rivers such as the Paraná River and Paraguay River influence to move of fish into higher latitudes. These species would use these systems as biodiversity corridors, producing a certain homogenization of the fish biodiversity between the different areas of South America.

The species that occurred in both ichthyogeographic provinces during the 60 's show a wide-range tolerance for different physical-chemical environmental parameters including total dissolved solids, temperature, $\mathrm{pH}, \mathrm{CO}_{3}{ }^{2-}, \mathrm{CO}_{3} \mathrm{H}, \mathrm{Cl}^{-}, \mathrm{SO}_{4}{ }^{2-}, \mathrm{Ca}^{2+}, \mathrm{K}^{+}, \mathrm{Mg}^{2+}, \mathrm{Na}^{+}$and $\mathrm{Mg} / \mathrm{Ca}$ relation $(\mathrm{Mg}+\mathrm{Ca}) /(\mathrm{Na}+\mathrm{K})($ Menni et al. 1996; Menni 2004). Some of the shared fish species with a wide-range tolerance were Astyanax fasciatus (Cuvier 1819), Oligosarcus jenynsii (Günther 1864), Hoplias malabaricus (Bloch 1794), Pterygoplichthys anisitsi (Eigenmann \& Kennedy 1903), Pimelodus maculatus (Lacepede 1803) and Rhamdia quelen (Quoy \& Gaimard 1824).

At the end of the 70's and beginning of the 80' several fish described as indicator species of the GRp (López \& Miquelarena 2005) appeared and were established in the Pp. The species are Callichthys callichthys (Linnaeus 1758), Cheirodon interruptus (Jenyns 1842), Pseudocorynopoma doriae (Perugia 1891), Pimelodella laticeps (Eigenmann 1917) and Cnesterodon decemmaculatus (Jenyns 1842). Remarkably, these species have a narrow 
tolerance range for the above-mentioned physical-chemical parameters suggesting that the present limnological conditions of the water bodies are appropriate for their survival, and that these conditions did not exist five decades ago. This is evident in the variations of the physicalchemical parameters in different sites of the North-East of Argentina during the last decades (Miquelarena et al. 1990, Menni et al. 1996, 2005).

The aquatic biota is known to be associated with the limnological features of bodies of water (Ringuelet, 1975). In particular, the species composition of a fish assemblage is closely related to the physical-chemical parameters of the freshwater habitat (Menni et al. 1996; Menni et al. 2005; Cussac et al. 2008).

The results of this study strongly suggest that the rainfall variations and river discharges observed in northeast Argentina induced changes in the composition of fish assemblages that lead to the redistribution of fish species among ichthyogeographic provinces. On this basis, it could be assumed that the ongoing climate change may influence the redistribution of fish species, including species with economic importance such as Prochilodus lineatus (Valenciennes 1837), Leporinus obtusidens (Valenciennes 1837), Salminus maxillosus (Cuvier 1816) (food), Corydoras paleatus (Jenyns 1842), Austrolebias nigripinnis (Regan 1912), Thoracocharax stellatus (Kner 1858) (ornamentals). Knowledge of the impact of environmental change on the composition of freshwater fish in other main ichthyogeographic provinces of South America would provide useful information for ensuring the sustainable management and conservation of fish biodiversity.

\section{ACKNOWLEDGMENTS}

We are grateful to Universidad de Buenos Aires (UBACYT 20020150100052BA) and CONICET (PIP 112-20120100543CO) and ANPCYT (PICT 2015-1823) for financial support. We also thank Servicio Meteorológico Nacional.

\section{REFERENCES}

Adams, S.M. \& M.S. Greeley. 2000. Ecotoxicological indicators of water quality: using multiresponse indicators to assess the health of aquatic ecosystems. Water, Air, \& Soil Pollution 123:103-115.

Arratia, G., M.B. Peñaflor, \& S. Menu-Marque. 1983. Peces de la región Sureste de los Andes y sus probables relaciones biogeográficas actuales. Deserta 7: 48-107.

Avigliano, E., A.Tombari \& A. Volpedo. 2011. ¿El otolito de pejerrey (Odontesthes bonariensis), refleja el estrés ambiental?. Biología Acuática 1-7.

Baldi, G., J.P. Guerschman, \& J.M. Paruelo. 2006. Characterizing fragmentation in temperate South America grasslands. Agriculture, Ecosystems \& Enviroment 116: 197-208.

Baldi, G. \& J.M. Paruelo. 2008. Land use and land cover dynamics in South American temperate grasslands. Ecology and Society 13(2): 1- 6.

Barros, V., M.E. Castañeda \& M. Doyle. 2000a. Recent precipitation trends in southern South America east of the Andes: An indication of climatic variability. In: P.P. Smolka \& W. Volkheimer (eds.). Southern Hemisphere Paleo and Neo-Climates, Springer-Verlag. p. 187-206.

Barros. V., M. González, B. Liebmann, \& I. Camilloni. 2000b. Influence of the South Atlantic convergence zone and South Atlantic sea surface temperature on interannual summer rainfall variability in southeastern South America. Theoretical and Applied Climatology 67: 123-133. 
Barros, V. R. Clarke, \& P. Silva Dias. 2006. El cambio climático en la Cuenca del Plata. Buenos Aires: Consejo Nacional de Investigaciones Científicas y Técnicas - CONICET, Buenos Aires, Argentina.

Barros, V. R., J.A. Boninsegna, I.A. Camilloni, M. Chidiak, G.O. Magrín, \& M. Rusticucci. 2015. Climate change in Argentina: trends, projections, impacts and adaptation. Wiley Interdisciplinary Reviews: Climate Change 6(2): 151-169.

Bates B., Z. Kundzewicz, S. Wu, \& J. Palutikof. 2008. Climate Change and Water. Technical Paper of the Intergovernmental Panel on Climate Change, IPCC Secretariat, Geneva

Bervery, E.H., M. Doyle \& V. Barros. 2006. Tendencias Regionales en la Precipitación. In: V. Barros , R. Clarke \& P. Silva Dias (eds.). El cambio climático en la Cuenca del Plata Consejo Nacional de Investigaciones Científicas y Técnicas - CONICET, Buenos Aires, Argentina. p. 6779.

Bonetto, A.A., D. Roldan \& M.E. Oliver. 1978. Estudios limnológicos en la cuenca del Riachuelo. I. Poblaciones de peces en ambientes leníticos y lóticos. Ecosur 5(9): 1-15.

Camilloni, I. A., R.I. Saurral, \& N.B. Montroull. 2013. Hydrological projections of fluvial floods in the Uruguay and Paraná basins under different climate change scenarios. International Journal of River Basin Management 11(4): 389-399.

Cussac, V.E., D.A. Fernández, S.E. Gómez \& H.L. López. 2008. Fishes of southern South America: a story driven by temperature. Fish Physiology and Biochemistry 35: 29-42.

Gómez, S.E., P.S. Trenti \& R.C. Menni. 2004. New fish populations as evidence of climate change in former dry areas of the pampean region (Southern South America). Physis (Buenos Aires) 59 (136-137): 43-44.

Gómez, S. \& R.C. Menni. 2005. Cambio ambiental y desplazamiento de la ictiofauna en el oeste de la Pampasia (Argentina Central). Biología Acuática 22: 151-156.

Liotta, J. 2006. Distribución geográfica de los peces de aguas continentales de la República Argentina. ProBiota - Serie Documentos 3: 1- 701.

Liotta, J. (comp.). 2014. Base de Datos sobre Peces de Aguas Continentales de la República Argentina. Publicación electrónica. http://www.pecesargentina.com.ar. Museo de Ciencias Naturales "P. Antonio Scasso".

López, H.L., C.C. Morgan, \& M.J. Montenegro. 2002. Ichthyological Ecoregions of Argentina. ProBiota - Serie Documentos 1: 1-70.

López, H.L., A.M. Miquelarena, \& R.C. Menni. 2003. Lista comentada de los peces continentales de la Argentina. ProBiota, Serie Técnica y Didáctica 5: 1-85.

López, H.L., \& A.M. Miquelarena.2005. Biogeografia de los peces continentales de la Argentina In: Llorente Bousquets J, Morrone JJ eds. Regionalización biogeogràfica en Iberoamérica y tópicos afines. Primeras Jornadas Biogeográficas de la Red Iberoamericana de Biogeografia y Entomología Sistemática (RIBES XII.I-CYTED), UNAM, México, D.F. pp 509-550

López, H.L., R.C. Menni, M. Donato, \& A.M. Miquelarena. 2008. Biogeographical revision of Argentina (Andean and Neotropical Regions): an analysis using freshwater fishes. Journal of Biogeography 35 (9): 1564-1579 
Magurran, A.E. 1988. Ecological diversity and its measurement. Princeton University Press, Princeton, New Jersey.

Malabarba, L.R., R.E. Reis, R.P. Vari, C.A.S. Lucena, \& Z. M.S. Lucena. 1998. Phylogeny and Classification of Neotropical Fishes. Museu de Ciencias e Tecnologia, PUCRS. Porto Alegre, Brazil.

Malcolm, J.R., C. Liu, R.P. Neilson, L. Hansen, \& L. Hannah. 2006. Global Warming and Extinctions of Endemic Species from Biodiversity Hotspots. Conservation Biology 20 (2): 538548.

Menni, R.C., A.M. Miquelarena, H.L. López, J.R. Casciotta, A.E. Almirón, \& L.C. Protogino. 1992. Fish fauna and environments of the Pilcomayo-Paraguay basins in Formosa, Argentina. Hydrobiologia 245:129-146.

Menni, R.C, S.E. Gómez \& M.S. López Armengol. 1996. Subtle relationships: Freshwater fishes and water chemistry in southern South America. Hydrobiologia 328: 173-197.

Menni, R.C. 2004. Peces y ambientes en la Argentina continental. Monografías del Museo Argentino de Ciencias Naturales 5, Buenos Aires.

Menni, R.C., A.M. Miquelarena, \& A.V. Volpedo. 2005. Fishes and environmental in northwestern Argentina (South America): from lowland to Puna. Hydrobiología 544 (1): 33-49.

Miquelarena, A.M., R.C. Menni, H.L. López, \& J.R. Casciotta. 1990. Ichthyological and limnological observations on the Sali river basin (Tucuman, Argentina). Ichthyological Exploration of Freshwaters, 1 (3): 269-276.

Monasterio de Gonzo, G. 2003. Peces de los ríos Bermejo, Juramento y cuencas endorreicas. Museo de Ciencias Naturales y Consejo de Investigación Universidad Nacional de Salta, Salta

Parmesan, C. 2006. Ecological and evolutionary responses to recent climate change. Annual Review of Ecology and Systematics, 37: 637-669.

Poulard, J.C. \& F. Blanchard. 2005. The impact of climate change on the fish community structure of the eastern continental shelf of the Bay of Biscay. ICES Journal of Marine Science 62(7): 1436-1443.

Preston, K.L., J.T. Rotenberry, R.A. Redak, \& M.F. Allen. 2008. Habitat shifts of endangered species under altered climate conditions: importance of biotic interactions. Global Change Biololgy 14: 2501-2515.

Ringuelet, R.A. 1962. Ecología acuática continental. EUDEBA, Buenos Aires.

Ringuelet, R.A., R.H. Arámburu \& A.A. de Arámburu. 1967. Los peces argentinos de agua dulce. Comisión de Investigaciones Científicas de la Provincia de Buenos Aires, Buenos Aires.

Ringuelet, R.A. 1975. Zoogeografía y ecología de los peces de aguas continentales de la Argentina y consideraciones sobre las áreas ictiológicas de América del Sur. Ecosur 2(3): 1122.

Root, T.L., J.T. Price, K.R. Hall, S.H. Schneider, C. Rosenzweig, \& J.A. Pounds. 2003. Fingerprints of global warming on wild animals and plants. Nature 421: 57-60. 
Schaefer, H., W. Jetz, \& K. Böhning-Gaese. 2008. Impact of climate change on migratory birds: community reassembly versus adaptation. Global Ecology and Biogeography, 17(1): 38-49.

Skelly, D.K, N. Liana, J. Hugh, P. Possingham, L. Freidenburg, T.J. Farrugia, K.T. Kinnison, \& A. Hendry. 2007. Evolutionary Responses to Climate Change. Conservation Biology 21 (5): 1353-1355.

Thomas, C.D., A. Cameron, R.E. Green, M. Bakkenes, L.J. Beaumont, Y.C. Collingham, B.F.N. Erasmus, M. Ferreira de Siqueira, A. Grainger, L. Hannah, L. Hughes, B. Huntley, A.S. van Jaarsveld, G.F. Midgley, L. Miles, M.A. Ortega-Huerta, A. Townsend Peterson, O.L. Phillips, \& S.E. Williams. 2004. Extinction risk from climate change. Nature 427: 145-148.

Volpedo, A.V., M.L Puntoriero, \& A. Fernández Cirelli. 2014. Cambios ambientales en el Lago Chasicó (Buenos Aires, Argentina) en las últimas décadas: impactos y perspectivas. 185-195 pp. En: "Fernández Reyes, L., A. Volpedo, M. Salgot. 2014. "Evaluación ambiental integral de ecosistemas degradados de Iberoamérica: experiencias positivas y buenas prácticas. Red CYTED Barcelona, España. 307 pp.

Williams, J.W., S.T. Jackson, \& J.E. Kutzbach. 2007. Projected distributions of novel and disappearing climates by 2100 AD. Proceedings of the National Academy of Sciences US104: 5738-5742.

Zar, J.H. 1999. Biostatistical analysis. 4th edn. Prentice Hall, Englewood Cliffs, New Jersey. 